\title{
Molecular Phylogeny of European Muroid Rodents Based on Complete Cytochrome b Sequences
}

\author{
Yvonne Martin,* Gabriele Gerlach,* Christian Schlötterer, $†$ and Axel Meyer* \\ * Department of Biology, University of Konstanz, 78457 Konstanz, Germany; and † Institut für Tierzucht und Genetik, \\ Veterinärmedizinische Universität W ien, A-1210 Vienna, Austria
}

Received June 25, 1999; revised December 3, 1999

Phylogenetic relationships among 18 species of mainly European muroid rodents that belong to three subfamilies were estimated using complete sequences of the mitochondrial cytochrome b gene. The inferred monophyly of the subfamilies Murinae (mice and rats) and Arvicolinae (voles, lemmings, and muskrats) is in agreement with previous studies. Within the Murinae, the morphology-based division of the genus Apodemus into three subgenera is supported by these DNA sequence data. The relationships among the different genera of the Murinae were generally poorly resolved, and the relationships of Micromys and Acomys to the other murine genera remained unresolved. Within the subfamily Arvicolinae, the relations of the genera Arvicola, Clethrionomys, and Microtus remained tentative with our data. However, within the Microtus group, there is a good molecular support for the phylogenetic relationships. These findings suggest that the origin of the different murine and arvicoline lineages was rapid, indicating an adaptive radiation with fast speciation. $\odot 2000$ Academic Press

Key Words: evolution; phylogeny; cytochrome b; muroid rodents; rapid radiation.

\section{INTRODUCTION}

Rodents are often used as model systems in a wide range of biological disciplines. While Mus and Rattus are the classical laboratory animals, behavioral studies were performed on many different rodent species within the past decades (Crowcroft, 1966; Robitaille and Bovet, 1976; Berry, 1981; McClintock, 1983; Elwood, 1985; Brown, 1986; Hurst, 1986; König and Markl, 1987; Gerlach, 1996; Gerlach, 1998). To explain the evolution of social behavior and other traits in this order of mammals, exact knowledge of their phylogenetic relationships is tantamount. Through the comparative method, one can address questions such as whether mating systems, social behavior such as cooperative behavior, or particular dispersal patterns have evolved independently. Currently, phylogenetic rela- tionships within the family Muridae, to which many of the most commonly studied rodents belong, remain uncertain.

The family Muridae is the largest mammalian family and accounts for approximately one-quarter of all mammalian species. It contains 1326 species, which are divided into 17 subfamilies (Musser and Carleton, 1993). Some of these subfamilies, such as Murinae, Sigmodontinae, Arvicolinae, and Gerbillinae, comprise large clades that contain approximately 225 genera worldwide with a broad geographic distribution. Three of these subfamilies are included in this study and we place special emphasis on the subfamilies Murinae and Arvicolinae.

In Europe, five genera of the subfamily Murinae (mice and rats) are found. They range in body size from 5 to $50 \mathrm{~cm}$ and are camouflaged in coloration. In general, their tails are long, and their eyes and ears are relatively large. There are many specializations, for example in habitat preference and social structures, and different mating systems are found within this subfamily. Representatives of all five genera of the Murinae are included in this study.

In comparison with the Murinae, the species of the subfamily Arvicolinae (voles, lemmings, and muskrats) have relatively small eyes and ears, and their tails are shorter than their bodies. The voles are the dominant rodent group in open grassland and cultivated land. In Europe, there are 11 genera found within the Arvicolinae. In our study, we examined 3 of the European genera.

The classification and evolution of the muroid rodent subfamilies Arvicolinae and Murinae have been studied by a variety of methods. Morphological, karyological, biochemical, and molecular data have all been used (Brownell, 1983; Gill et al., 1987; Catzeflis et al., 1987; Chaline and Graf, 1988; Robinson et al., 1997). Initial attempts to classify rodent families were based on dental structures of fossil and extant rodents. The phylogenetic relationships among the Murinae (Misonne, 1969) and Arvicolinae (Niethammer and Krapp, 1982) were based largely on differences in their molar mor- 
phology. In some cases, the results of morphological studies contradict results that are obtained with biochemical and molecular characters. For example, controversy persists about the relationships among the genera Arvicola, Microtus, and Clethrionomys. According to Rabeder (1980), the genera Microtus and Clethrionomys are more closely related to each other than they are to Arvicola (Niethammer and Krapp, 1982). In contrast, studies of allozymes (Graf and Scholl, 1975) and DNA/DNA hybridization data (Catzeflis et al., 1987) suggest that the genera Microtus and Arvicola are more closely related. No DNA sequence data relevant to this question were available before this study.

Also, the phylogenetic relationships among members of the subfamily Murinae are still somewhat unresolved. Based on morphological features, Mus and Rattus are believed to be more cl osely related to each other than Mus is to Apodemus (Misonne, 1969). However, Catzeflis et al. (1987) using DNA/DNA hybridization data and Nikoletopoulos et al. (1992) using immunological data postulated that Mus and Apodemus form the sister group to Rattus.

Even more contentious have been the phylogenetic relationships among the genera Acomys and Micromys relative to the other murine genera. Both share a unique molar tooth pattern with the other murine genera, but, particularly in morphological characters, they differ strongly from other genera within the subfamily Murinae. Acomys has a different coat with rigid bristles and Micromys has differently shaped sperm and a different skull with a relatively larger and elongated cerebral region and a rather shortened rostral region.

Robinson et al. (1997) were the first to use DNA sequences of the nuclear LCAT gene for the determination of the phylogenetic relations among the Muroidea. However, their phylogenetic analysis included only a few genera from the different subfamilies, and important genera of the Murinae and Arvicolinae, such as Apodemus or Arvicola, were not included. Different genes were sequenced for species of the Murinae and Arvicolinae, but no large sets of homologous sequences were available to compare these European rodent species. For a multitude of comparative studies in many biological disciplines, it is important to know exactly the phylogenetic relationships between the different rodent model systems.

To investigate the phylogenetic relationships among European muroid rodents, we determined the complete sequences of the mitochondrial cytochrome b gene. The widespread successful use of the cytochrome $b$ gene (cyt b) made this gene the obvious choice as a phylogenetic marker for this study (Meyer, 1994). The wide availability of cytochrome $b$ sequences further permits comparison of our data with some previously published sequences, such as that of Mus domesticus (Bibb et al., 1981), Rattus norvegicus (Gadaleta et al., 1989), and
Acomys cahirinus (Barome et al., 1998), and choice among several available outgroup taxa.

\section{MATERIALS AND METHODS}

\section{Specimens Examined}

Our analysis included 18 muroid rodent species, which belong to three subfamilies: 12 species belong to the subfamily Murinae (mice and rats), 5 species be long to the Arvicolinae (voles and lemmings), and 1 species belongs to the Gerbillinae (gerbils) (Table 1). Four outgroup taxa were included from previously published sources; these are Chelemys macronyx (Accession No. U03533; Smith and Patton, 1999), Geoxus valdivianus (Accession N o. U 03531; Smith and Patton, 1999), Kunsia tomentosus (Accession No. AF 108670; Smith and Patton, 1999), and Lenoxus apicalis (Accession No. U03541; Smith and Patton, 1999). These outgroup taxa all belong to the subfamily Sigmodontinae (New World cricetids).

\section{DNA Extraction}

Total genomic DNA was extracted from small (4$\mathrm{mm}^{2}$ ) pieces of muscle or ear tissue. The tissue was digested overnight at $47^{\circ} \mathrm{C}$ in a total volume of $400 \mu \mathrm{l}$, including $53 \mu \mathrm{l}$ proteinase $\mathrm{K}(14 \mathrm{mg} / \mathrm{ml}$ ) (Boehringer Mannheim) and $347 \mu \mathrm{l}$ ATL Tissue Lysis Buffer (Qiagen), and were subjected to standard phenol/chloroform extraction and ethanol precipitation (Sambrook et al., 1989).

\section{DNA Amplification and Sequencing}

Mitochondrial sequences containing the cytochrome b gene were isolated via the polymerase chain reaction (PCR). The entire cyt b gene was amplified using the primers L14115 (5'-AAT GAC ATG AAA CAT CGT TG-3') and H15288 (5'-ACA AGA CCA GAG TAA TGT TTA TAC TAT C-3') in the flanking region of the glutamin and threonin tRNA genes. Additional internal primers used only for sequencing were L 14648 (5'-TGA ATY TGA GGR GGC TTC TCA GTA-3') and H14742 (5'-GGG TTG TTD GAT CCW GTT TC-3'). Primer names indicate the DNA strand $(H$, heavy or $L$, light) and the position of the most $3^{\prime}$ end of the oligonucleotide with reference to the Mus domesticus mtDNA sequence (Bibb et al., 1981).

Double-stranded PCR amplifications were performed in $40-\mu \mathrm{l}$ reaction volumes using primers L14115 and H15288. Each reaction included $2 \mu \mathrm{l}$ primer $(20 \mu \mathrm{M}), 4 \mu \mathrm{l}$ of deoxynucleoside-triphosphate mixture, $4 \mu \mathrm{l} 10 \times$ reaction buffer (Pharmacia), and 0.2 $\mu$ l Taq DNA polymerase (5 U/ $/ \mu$, Pharmacia). All PCRs used the following thermal cycling parameters: 2 min at $94^{\circ} \mathrm{C}, 40 \mathrm{cycles}\left(1 \mathrm{~min}\right.$ at $94^{\circ} \mathrm{C}, 1 \mathrm{~min}$ at $52^{\circ} \mathrm{C}$, and 2 min at $72^{\circ} \mathrm{C}$ ), plus $15 \mathrm{~min}$ at $72^{\circ} \mathrm{C}$, in a PTC 100 thermal cycler (Biozym). PCR products were gel-purified in $0.8 \%$ agarose. 
TABLE 1

Species of Muroid Rodents Included in the Phylogenetic Analysis

\begin{tabular}{|c|c|c|}
\hline Subfamily & Species & $\begin{array}{l}\text { Origin of sample or previous } \\
\text { sequence (citation given) }\end{array}$ \\
\hline \multirow[t]{12}{*}{ Murinae } & Acomys cahirinus & Z96053 (Barome et al., 1998) \\
\hline & Apodemus agrarius & MVZFC 5214 \\
\hline & Apodemus al picola & Switzerland \\
\hline & Apodemus flavicollis & Konstanz (Germany) \\
\hline & Apodemus microps & $\mathrm{T}-850$ \\
\hline & Apodemus mystacinus & $\mathrm{T}-851$ \\
\hline & Apodemus sylvaticus & Konstanz (Germany) \\
\hline & Micromys minutus & Konstanz (Germany) \\
\hline & Mus domesticus & J 01420 (Bibb et al., 1981) \\
\hline & Mus spicilegus & $\mathrm{T}-408$ \\
\hline & Mus spretus & T-392 \\
\hline & Rattus norvegicus & X14848 (Gadaleta et al., 1989) \\
\hline \multirow[t]{5}{*}{ Arvicolinae } & Arvicola terrestris & MVZFC 4873 \\
\hline & Clethrionomys glareolus & Konstanz (Germany) \\
\hline & Microtus agrestis & Lengwil (Switzerland) \\
\hline & Microtus arvalis & Wolfach (Germany) \\
\hline & Microtus epiroticus & MVZFC 5216 \\
\hline Gerbillinae & Meriones unguiculatus & Institut für Haustierkunde Kiel \\
\hline \multirow[t]{4}{*}{ Sigmodontinae } & Chelemys macronyx & U 03533 (Smith and Patton, 1999) \\
\hline & Geoxus valdivianus & U 03531 (Smith and Patton, 1999) \\
\hline & Kunsia tomentosus & AF 108670 (Smith and Patton, 1999) \\
\hline & Lenoxus apicalis & U 03541 (Smith and Patton, 1999) \\
\hline
\end{tabular}

Note. Listing is al phabetical and does not reflect phylogenetic relationship. T numbers refer to the catalogue of mammalian tissues curated at the University of Montpellier (Catzeflis, 1991). MVZ are catalogue numbers of specimens from the Museum of Vertebrate Zoology (University of California, Berkeley).

All taxa were sequenced directly from purified PCR products using the primers mentioned above. Approximately $100 \mathrm{ng}$ of double-stranded PCR product was used in cycle sequencing reactions using the $A B I$ Prism BigDye Terminator Cycle Sequencing Ready Reaction $\mathrm{Kit}$ (Applied Biosystems). All sequencing reactions were performed according to the manufacturer's instructions. Sequencing was done on an ABI Prism Automated 377 HT DNA Sequencer (Applied Biosystems). Sequences for both strands were determined.

All sequences are available in GenBank/EMBL under Accession Nos. AF 159390-AF 159405.

\section{Phylogenetic Analysis}

Phylogenetic relationships were analyzed by maximum-parsimony (MP), neighbor-joining (NJ), and maximum-likelihood (ML) methods. The phylogenetic analyses were conducted using the program PAUP* test version 4.0d65 (Swofford, 1998). Critical values of skewness ( $g_{1}$ statistics) of the tree length distribution were used to assess overall phylogenetic signal in the data set (Hillis and Huelsenbeck, 1992). The critical values were computed from a distribution of 10,000 randomly generated trees using PAUP. The maximumparsimony analysis was done with a heuristic search using stepwise addition and performing tree- bisection-reconnection (TBR) branch swapping. We employed several weighting schemes to correct for the possible saturation for third position transitions and to accommodate the cytosine to thymine $(\mathrm{C} \leftrightarrow \mathrm{T})$ changes at first positions that specify different codons of leucine. In the first weighting scheme, the transitions at the third codon position and the $\mathrm{C} \leftrightarrow \mathrm{T}$ substitutions for leucine at the first codon position were excluded. I n the second, we used a 10:1 transversion to transition weight for third positions, a weight of 10 for all second positions, and a weight of 1 for all first position $\mathrm{C} \leftrightarrow \mathrm{T}$ substitutions, with all others weighted 10. The 10:1 third position transition to transversion ratio was the empirically observed rate difference. Support for each clade in the most parsimonious reconstructions was assessed by bootstrap (BP) analysis from 500 bootstrap replicas. Neighbor-joining analyses were performed with distance matrices calculated with the Kimura two-parameter model, and the robustness of inferences was assessed through bootstrap resampling (1000 repetitions). Maximum-likelihood analyses were performed with the Hasegawa-Kishino-Yano model (Hasegawa et al., 1985) and the empirically observed transition:transversion ratio of 1.98 .

The maximum-likelihood method was used for statistically testing alternative topologies against the one with the highest likelihood. This test of Kishino and Hasegawa (1989) uses the mean and variance of loglikelihood differences between trees. If the mean is 
more than 1.96 standard deviations different, then the trees are declared significantly different. The topology of the ML tree was constrained according to the alternative topologies obtained by the MP or NJ method.

\section{RESULTS}

\section{Cytochrome b Gene Sequences}

The complete cytochrome b gene was determined for 15 taxa and analyzed together with additional previously published muroid rodent sequences. The gene begins in all examined species with the conserved initiating methionine codon ATG. Within the Arvicolinae, the gene has the stop codon TAA. Within the Murinae, there is, except for Rattus norvegi cus, no complete stop codon. There is a single $T$ at the $5^{\prime}$ end of the following tRNA gene. The cytochrome $b$ gene ends with a translational termination signal, which is presumably produced by the polyadenylation of the processed mRNA, as in many animal mitochondrial genomes (Anderson et al., 1981). There are slight differences in gene length in different rodent groups-within the Arvicolinae, it is $1143 \mathrm{bp}$ and in some Murinae the gene is 1144 bp long. In some hystricognath rodents, the gene is also 1143 bp long (Ma et al., 1993), but in many other rodents, the gene is at the end one codon shorter (DeWalt et al., 1993; Thomas and Martin, 1993; Lara et al., 1996; Lessa and Cook, 1998).

\section{Base Composition}

Base composition of the cytochrome $b$ gene in the examined muroid rodents was quite similar to that of previously reported mammalian sequences (Irwin et al., 1991) and comparable to values found in some caviomorph rodents (Lara et al., 1996; Lessa and Cook, 1998). As expected, the abundance of Gs was low (12.8\%), whereas the percentages of $A, T$, and $C$ were quite similar (27.7-30.8\%). The frequency of guanine differs greatly among the three codon positions. At the first position, the content is $22.3 \%$, at the second position, it is $12.9 \%$, and at the third position, guanine is rare $(3.1 \%)$. Second positions have more thymine (42.4\%), whereas first and third positions are richer in adenine (29.8 and $42.2 \%$ ). These values are similar to base compositional patterns previously found in various mammalian species, including some caviomorph rodents (I rwin et al., 1991; Lara et al., 1996; Lessa and Cook, 1998). The bias in base composition was calculated as in Irwin et al. (1991). Compositional bias is smaller at first and second positions (0.0633 and 0.2313 ) than at third positions (0.3607). As expected, the first and second codon positions show less variability than third codon positions (I rwin et al., 1991).

\section{Sequence Variation}

For the phylogenetic analyses, a data set of 18 species and 1140 nucleotides was used and could be un- ambiguously aligned. Of these sites, 512 were variable and 416 were parsimony informative; 123 (24\%) of the variable nucleotides were at first codon positions, 39 (8\%) were at second codon positions, and 350 (68\%) were at third codon positions. Of the phylogenetically informative sites, 86 (21\%) were at first positions, 18 (4\%) were at second positions, and 312 (75\%) were at third positions. As expected for this phylogenetic "depth," most variable sites were in third codon positions.

\section{Genetic Distances}

Within genera the genetic distances (corrected with the Kimura two-parameter model) range from 6 to $15 \%$. This is similar to genetic distances within other rodent genera, which are known to span a wide range of divergence. For example, within some genera of caviomorph rodents, between 9 and 20\% sequence divergence have been reported (Lara et al., 1996). The values can be about as great as those among some genera, which range in our study from 15.5 to $20.3 \%$. The sequence divergence between genera of the different subfamilies is in a range from 21 to $32 \%$. This is also comparable to those reported distances between 20 and even $40 \%$ of some caviomorph rodents of the family Echimyidae (Lara et al., 1996).

\section{Phylogenetic Analysis of the Muridae}

Phylogenetic trees based on maximum-parsimony, neighbor-joining, and maximum-likelihood methods were calculated (Figs. 1, 2, and 3). The different weighting schemes in parsimony analysis produced similar trees with the same tree topologies. Conse quently, only results with exclusion of the first position $\mathrm{C} \leftrightarrow \mathrm{T}$ changes and without third position transitions are presented (Fig. 1). The strength of phylogenetic signal in the data set was assessed from the length distribution of 10,000 random trees for both weighting schemes. Skewness was investigated for all sequences and subsets of taxa, because significant skewness can result from only one strongly supported clade. The analysis first contained all sequences, but clades were subsequently taken out to represent all hierarchical levels in the tree. When all sequences are considered, the $g_{1}$ statistic is highly significant $\left(g_{1}=-0.654\right.$; $\mathrm{P}<0.01$ ). Also, with subsets of taxa, there is a highly significant skew in the distribution, indicating strong phylogenetic signal under both step matrices.

\section{Phylogenetic Relationships of the Muridae}

With all three methods, the Arvicolinae form a strongly supported clade with bootstrap values of 98 and $100 \%$; however, the monophyly of the subfamily Murinae was not quite as convincingly supported (bootstrap values between 65 and 99\%). The only representative species of the Gerbillinae examined, Meriones unguiculatus, forms, together with the Murinae, a sister group to the Arvicolinae. Phylogenetic relation- 


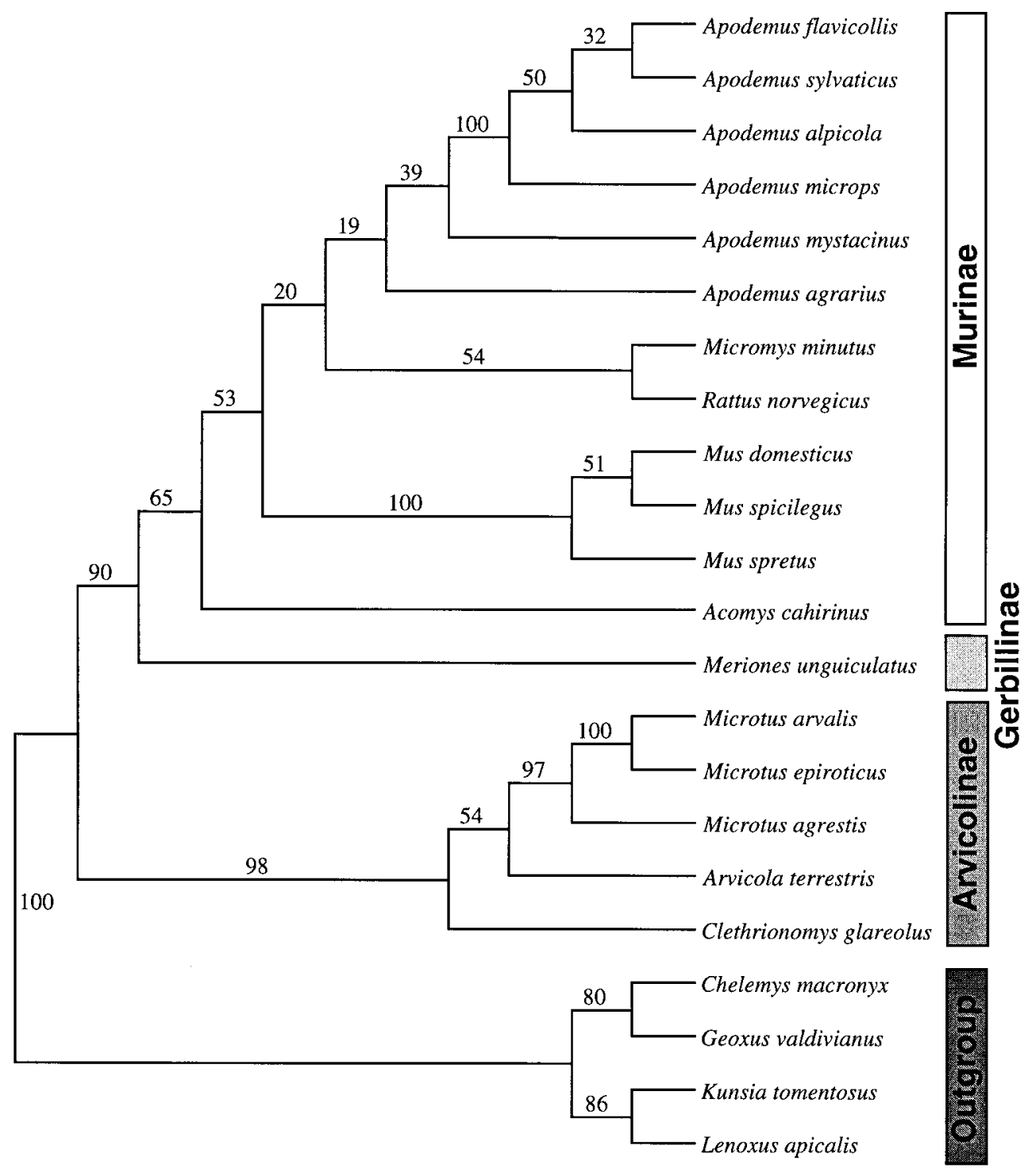

FIG. 1. Phylogenetic tree showing the relationships of the different species of the subfamilies Murinae, Arvicolinae, and Gerbillinae. It is based on a maximum-parsimony analysis of complete cytochrome $b$ gene sequences. In the weighting scheme, the transitions at the third codon position and the $\mathrm{C} \leftrightarrow \mathrm{T}$ substitutions for leucine at the first codon position were excluded. The numbers above branches are bootstrap values obtained in 500 replicates. The species Chelemys macronyx, Geoxus valdivianus, Kunsia tomentosus, and Lenoxus apicalis were used as outgroup.

ships among the different genera were not always clearly resolved by cytochrome b sequences. Among the arvicoline genera, the resolution is good, but the phylogenetic relationships of the murine genera remain partly unresolved, especially the relationships among the genera Apodemus, Mus, and Rattus. A NJ analysis based on 10 sequences of the Murinae, but only two species of the Arvicolinae as outgroup, was conducted (Fig. 4). Some of the bootstrap values within the Murinae were higher than those in the previous analyses, which included all species. The partial analysis showed that Mus and Apodemus together form the sister group to Rattus.

\section{DISCUSSION}

The results of our phylogenetic analysis are largely consistent with expectations based on previous studies. The distinction between the subfamily Murinae and the subfamily Arvicolinae is also supported by morphological characters, such as the different structure of their molars. Also, with DNA/DNA hybridization data and DNA sequence data of the nuclear LCAT gene, the monophyly of these subfamilies is supported (Catzeflis et al., 1987; Robinson et al., 1997). A close relationship of the subfamilies Murinae and Gerbillinae was also found in the study of Dubois et al. (1999), which is 


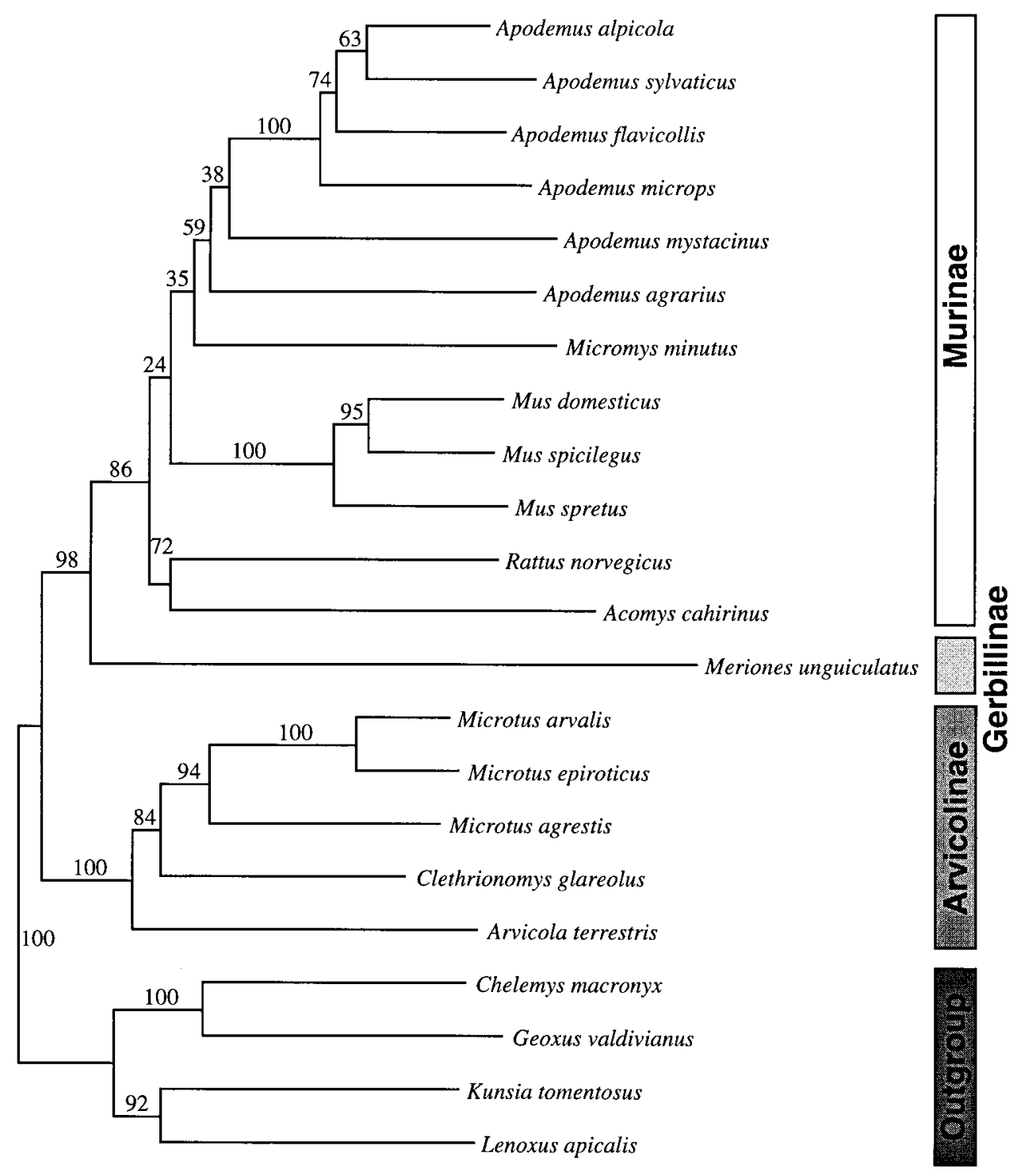

0.05 changes

FIG. 2. The phylogenetic tree shown is a neighbor-joining reconstruction performed on a Kimura two-parameter corrected distance matrix. Numbers represent percentage bootstrap support values of 1000 replicates. Branch lengths are proportional to the genetic distance.

based on sequences of the nuclear pancreatic ribonuclease A gene.

The Subfamily Murinae

The phylogenetic relationships determined for the murine genera Mus, Apodemus, and Rattus in this study are in agreement with the results of Catzeflis et al. (1987) and Nikoletopoulos et al. (1992). Good resolution was obtained for the different Mus species. With all phylogenetic methods used in this study, the relationships are stable and in agreement with those inferred from previous published D-loop data (Prager et al., 1996).
The genus Apodemus. With all methods used in this study (MP, NJ , and ML), the genus Apodemus is a monophyletic clade, but sometimes with quite low bootstrap values (e.g., MP analysis). The subgenus Sylvae mus, with the species A. alpicola, A. sylvaticus, A. flavicollis, and A. microps, forms a monophyletic group, which is strongly supported (bootstrap value is al ways $100 \%$ ), and accordingly the species A. agrarius and A. mystacinus are al ways placed outside this group. With the NJ and ML methods, A. alpicola appears to be more closely related to A. sylvaticus than to A. flavicollis. With the MP method, A. al pi col a is a sister taxon to A. flavicollis and A. sylvaticus. The $\mathrm{KH}$ test of these 


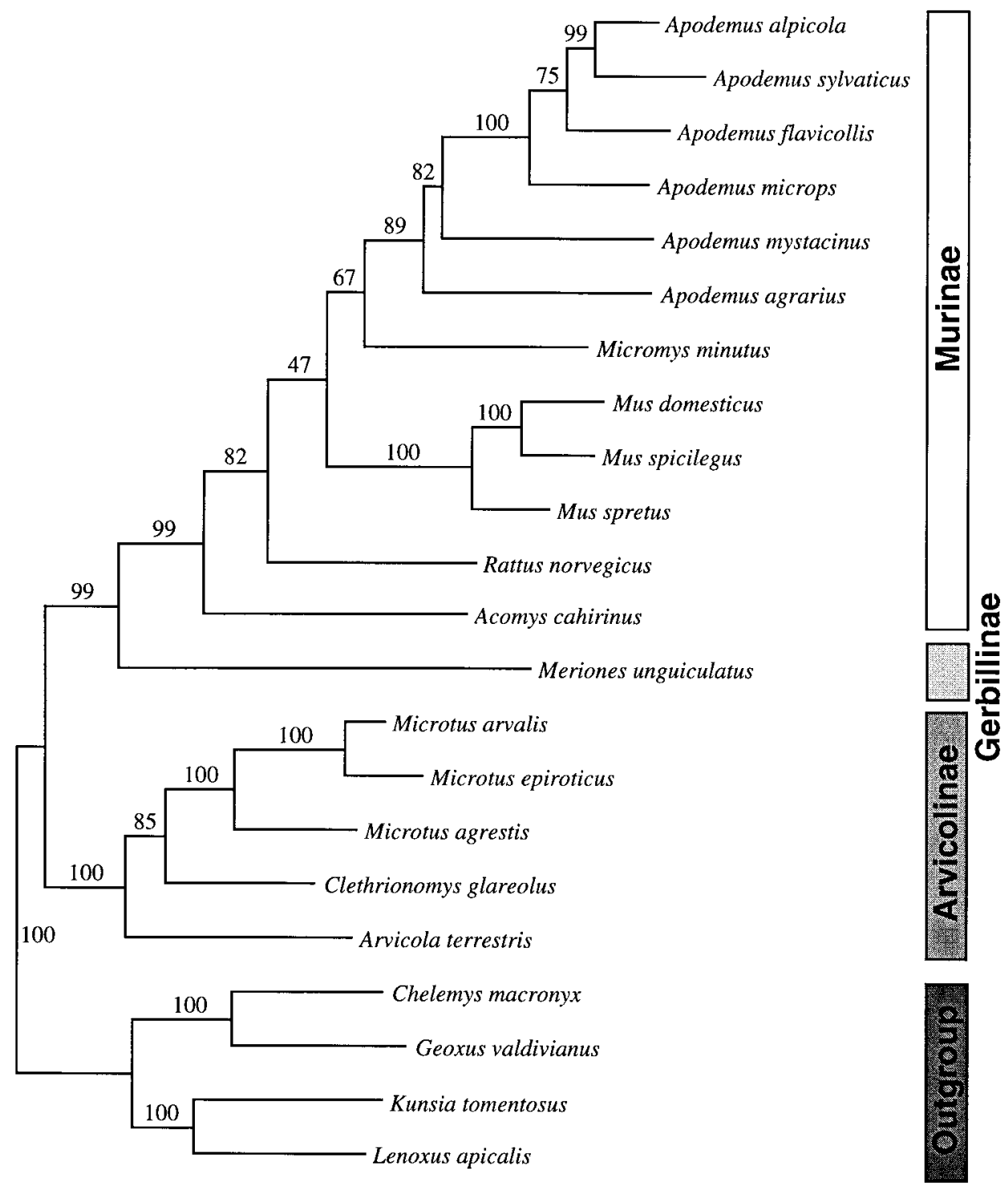

0.05 substitutions/site

FIG. 3. Maximum-likelihood reconstruction assuming the HKY model of evolution (Hasegawa et al., 1985) and a transition:transversion ratio of 1.98. The outgroup taxa are Chelemys macronyx, Geoxus valdivianus, Kunsia tomentosus, and Lenoxus apicalis. Values are quartet puzzling reliability percentages.

different alternative tree topologies was not significant (Table 2). In the allozyme study of Vogel et al. (1991), A. al pi cola is also more closely related to A. sylvaticus, whereas in a previous study of Filipucci (1987), A. al picola is placed together with A. flavicollis. The genetic distances among the species in the subgenus Sylvaemus are between 8 and 12\%. The genetic distances of the subgenus Sylvaemus to the species A. mystacinus and $A$. agrarius are between 16 and 19\%, which is as great as those of the Sylvaemus group to other murine genera. An allozyme study of Britton-Davidian et al. (1991) also shows a great genetic distance of A. agrarius to the Sylvaemus group, whereas A. mystacinus is not so extremely distant. Based on morphological characters, the genus Apodemus is divided into three subgenera: the subgenus Apodemus with $A$. agrarius; the subgenus Sylvaemus with $A$. sylvaticus, A. flavicollis, A. al picola, and A. microps; and the subgenus Karstomys with A. mystacinus (Niethammer and Krapp, 1978). Our cytochrome b sequence data support the same subdivision.

The genus Acomys. For Acomys, different results are obtained with the MP, NJ , and ML methods. With 


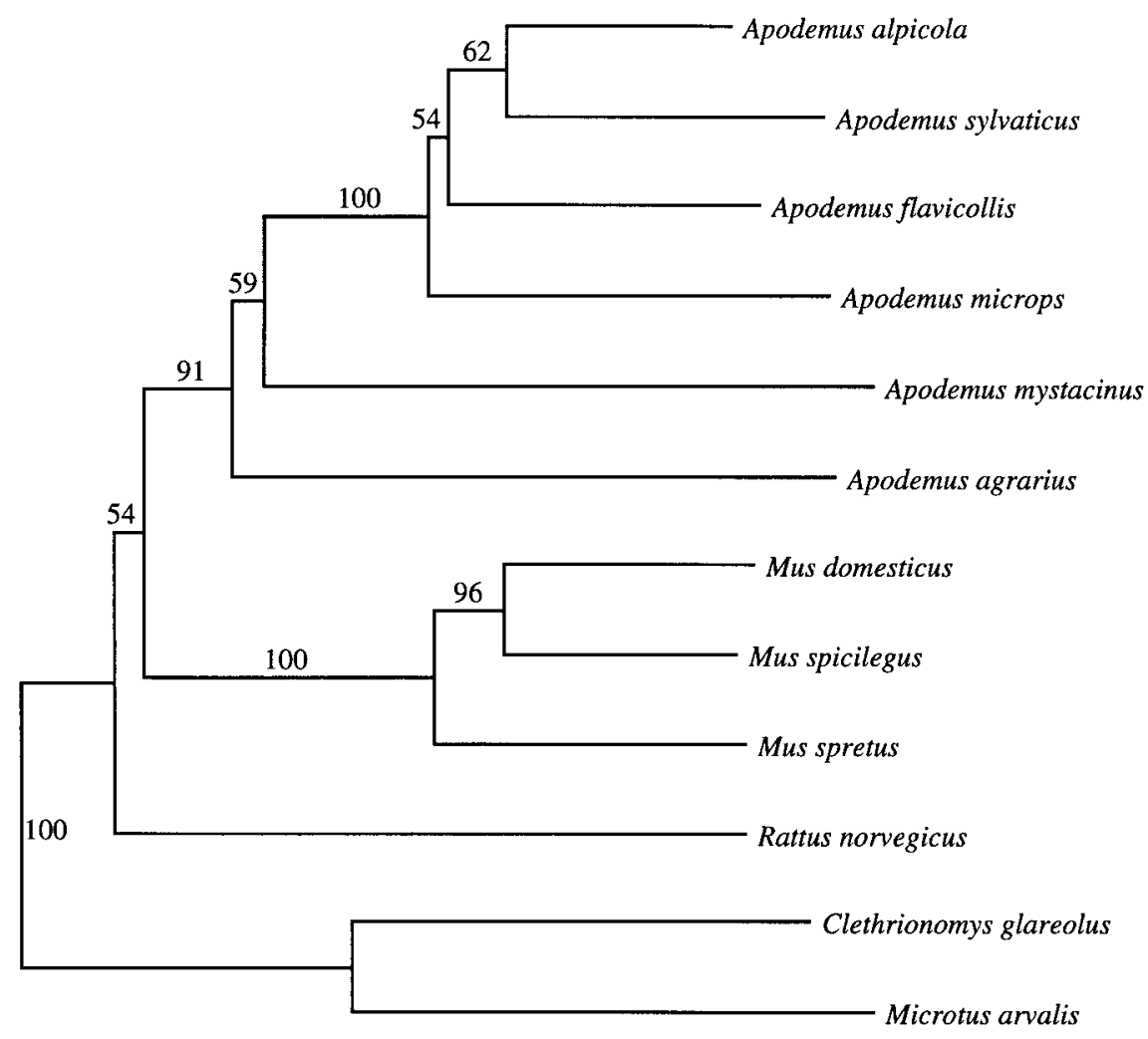

0.05 changes

FIG. 4. The phylogenetic tree shown is a partial analysis of the Murinae with the neighbor-joining method (Kimura two-parameter model) and two species of the Arvicolinae as outgroup (Clethrionomys gl areol us and Microtus arvalis). Numbers above branches are bootstrap values obtained in 1000 replicates.

maximum-parsimony and maximum-likelihood, Acomys is identified as sister taxon to the other genera of the Murinae (Figs. 1 and 3). In the neighbor-joining analyses, Acomys is placed together with Rattus norvegicus as a sister group to the other murine genera (Figs. 2 and 4). Unfortunately, the position of Acomys relative to the other examined species remains unresolved with the cytochrome b data. The log likeli- hood test shows that the difference between these alternatives is not significant at the $\mathrm{P}<0.05$ level (Table 2).

The determination of the phylogenetic position of the genus Acomys (spiny mice) has been difficult and its taxonomic position remains controversial. Based on morphological data, especially due to their similar molar structure, it was assumed that Acomys belongs to

\section{TABLE 2}

\section{Log-Likelihood Ratio Tests for the Comparison of Unconstrained and Constrained Maximum-Likelihood Topologies Generated from Cytochrome b Sequence Data}

\begin{tabular}{lcrr}
\hline Comparison & Log likelihood (LnL) & Difference LnL & Standard deviation \\
\hline ML tree vs MP topology (Clgl/ Arte) & -12069.31 & -3.54 & 6.04 \\
ML tree vs MP topology (Apfl/ Apal) & -12072.85 & -13.36 & 0.56 \\
ML tree vs MP topology (Acca/ Rano) & -12069.31 & -9.72 & 0.08 \\
ML tree vs MP topology (Mimi/ Rano) & -12082.67 & -12069.31 & 0.37 \\
& -12059.57 & 0.12 & 12.45 \\
\hline
\end{tabular}


the Murinae and was a close relative to Mus ( $\mathrm{J}$ acobs, 1978). However, immunological results of Sarich (1985) showed that Acomys is as distant from Mus as it is from other subfamilies of the Muridae. Chevret et al. (1993) examined the relationships of Acomys to other rodent species with DNA/DNA hybridization data and found a closer relationship of Acomys to the subfamily Gerbillinae (gerbils) than to the Murinae. Another indication that Acomys is not a member of the Murinae is the distribution of $L 1$ repeated DNA el ements. In many genera of the Murinae, there are $L x$ sequences, which are an ancient amplification of the L 1 family, but these sequences are not found in other subfamilies, such as the Arvicolinae, Gerbillinae, and Cricetinae, and are not found in Acomys (Furano et al., 1994). In a phylogenetic analysis based on DNA sequences of the fifth exon of the kallikrein-binding protein gene, a close relationship between Acomys cahirinus and Meriones unguiculatus, which belongs to the Gerbillinae, was found (Agulnik and Silver, 1996). In a recent study of Dubois et al. (1999), a subfamily level for Acomys and Uranomys (Acomyinae) was suggested based on sequences of the nuclear pancreatic ribonuclease $A$ gene. The cytochrome b data al so suggest an early separation of Acomys from the other murine genera.

The genus Micromys. The position of Micromys differs according to the method of analysis of our cytochrome $b$ data. With the MP method, Micromys is placed as sister taxon to Rattus, but with a bootstrap value of only $54 \%$, whereas with the $\mathrm{NJ}$ method, it is identified as sister taxon to Apodemus (BP 35\%). The same result is obtained with the maximum-likelihood method, but with a higher bootstrap value of $67 \%$. Similar to Acomys, the position of Micromys relative to the other murine genera remains unresolved with the cytochrome b data. A Log likelihood test showed no significant difference between the alternative tree topologies (Table 2).

Similar to Acomys, the phylogenetic position of $\mathrm{Mi}$ cromys also has been controversial. Micromys has the characteristic molar pattern of Progonomys, the presumed ancestor of the Murinae, and of the recent species of the Murinae, such as Apodemus; so a close relationship with this genus has been assumed (Misonne, 1969). However, other morphological features, such as the form of the skull and the sperm, show that Micromys differs from the other species of the subfamily Murinae. In the study of Furano et al. (1994), a relatively small expansion of the Lx family in Micromys compared to other recent murine species was found. Therefore, they assumed that this genus diverged early from the main murine lineage. With DNA sequence data of the nuclear gene LCAT, there was also no resolution regarding this matter (Robinson et al., 1997).

\section{The Subfamily Arvicolinae}

With the cytochrome b data, different tree topologies regarding the question of the relationship of Arvicola and $\mathrm{Clethrionomys}$ relative to $\mathrm{Microtus}$ are recovered. With MP, Arvicola and Microtus are more closely related to each other than both are to Clethrionomys. With $\mathrm{NJ}$ and $\mathrm{ML}$, Clethrionomys and Microtus are more closely related to each other and form a sister group to Arvicola. There is no significant difference between the alternative hypotheses (Table 2). The resolution within the genus Microtus is good, with high statistical values for all three analysis methods (Figs. 1-3). M. arvalis and M. epiroticus together form the sister group to $\mathrm{M}$. agrestis.

Within the Arvicolinae, the morphology-based relationships among the genera are based on dentitional differences. Based on these structures, the genera $\mathrm{Mi}$ crotus and Clethrionomys are more closely related to each other than both are to Arvicola (Niethammer and Krapp, 1982). However, biochemical data (Chaline and Graf, 1988) and DNA/DNA hybridization data (Catzeflis et al., 1987) suggested a cl oser relationship between Microtus and Arvicola. With our data, the alternative placement cannot be rejected.

\section{Divergence Times}

Based on a good fossil record, molecular clocks can be calibrated for genes. Such a molecular clock has been calibrated for cytochrome b (Smith and Patton, 1993). A rate of change can be calculated based on the transversions at the third codon position and the divergence of Mus and Rattus. Paleontological data suggest the split of mice and rats at 12-14 Myr (J aeger et al., 1986; J acobs et al., 1989, 1990). If a divergence time of 12 Myr is accepted, then the rate of change is $1.6 \%$ per Myr. The calculated divergence times for the murine genera are between 9 and 13 mya and for the arvicoline genera between 7 and 8 mya. This period of time is rather short and could be an indication that the origin of the different murine and arvicoline lineages was rapid and that a fast radiation of new lineages took place.

The degree of resolution for the reconstruction of phylogenetic relationships among the examined taxa was surprisingly variable. Among some species, such as Mus or Microtus, the relationships are stable and all phylogenetic methods support them with high bootstrap values. Generally, the resolution of relationships among different species within one genus was quite good. In other studies, the resolution among closely related species with cytochrome b data is good (Barome et al., 1998; Ducroz et al., 1998). On the other hand, there are species, such as Acomys and Micromys, which cannot be assigned a firm phylogenetic position with these data and the recovered topologies are different with different phylogenetic methods. Among the Murinae, the resolution is weak above the species level. In 
other studies also, only weak resolution at the genus or family level was found (Lessa and Cook, 1998; Lara et al., 1996; Verheyen et al., 1995). One explanation is that not enough phylogenetic information is available due to saturation, but the tree length distributions are significantly skewed, indicating high phylogenetic information content in the data. Another possible explanation for the weak resolution above the species level is that it is caused by the rapid evolution of different lineages. Hence, an adaptive radiation may be the biological reason for the weak resolution among the genera of European muroid rodents.

\section{ACKNOWLEDGMENTS}

We thank J ames L. Patton at the Museum of Vertebrate Zoology (University of California, Berkeley), François M. Catzeflis at the University of Montpellier, and the Institut für Haustierkunde (Kiel) for kindly providing some of the samples. We thank the Deutsche Forschungsgemeinschaft and the University of Konstanz for financial support.

\section{REFERENCES}

Agulnik, S. I., and Silver, L. M. (1996). The Cairo spiny mouse Acomys cahirinus shows a strong affinity to the Mongolian gerbil Meriones unguiculatus. Mol. Biol. Evol. 13: 3-6.

Anderson, S., Bankier, A. T., Barrel, B. G., de Bruijn, M. H. L., Coulson, A. R., Drouin, J ., Eperon, I. C., Nierlich, D. P., Roe, B. A., Sanger, F., Schreier, P. H., Smith, A. J . H., Staden, R., and Young, I. G. (1981). Sequence and organization of the human mitochondrial genome. Nature 290: 457- 465.

Baker, R. J ., Van Den Bussche, R. A., Wright, A. J ., Wiggins, L. E., Hamilton, M. J ., Reat, E. P., Smith, M. H., Lomakin, M. D., and Chesser, R. K. (1996). High levels of genetic change in rodents of Chernobyl. Nature 380: 707-708.

Barome, P.-O., Monnerot, M., and Gautun, J .-C. (1998). Intrageneric phylogeny of Acomys (Rodentia, Muridae) using mitochondrial gene cytochrome b. Mol. Phylogenet. Evol. 9: 560-566.

Berry, R. J . (1981). "Biology of the House Mouse," Academic Press, London.

Bibb, M. J., Van Etten, R. A., Wright, C. T., Walberg, M. W., and Clayton, D. A. (1981). Sequence and gene organization of mouse mitochondrial DNA. Cell 26: 167-180.

Britton-Davidian, J ., Vahdati, M., Benmehdi, F., Gros, P., Nancé, V., Croset, H., Guerassimov, S., and Triantaphyllidis, C. (1991). Genetic differentiation in four species of Apodemus from southern Europe: A. sylvaticus, A. flavicollis, A. agrarius and A. mystacinus (Muridae, Rodentia). Z. Säugetierk. 56: 25-33.

Brown, R. E. (1986). Social and hormonal factors influencing infanticide and its suppression in adult male Long-Evans Rats (Rattus norvegicus). J . Comp. Psychol. 100: 155-161.

Brownell, E. (1983). DNA/DNA hybridization studies of muroid rodents: Symmetry and rates of molecular evolution. Evolution 37: 1034-1051.

Catzeflis, F. M., Sheldon, F. H., Ahlquist, J . E., and Sibley, C. G. (1987). DNA-DNA hybridization evidence of the rapid rate of muroid rodent DNA evolution. Mol. Biol. Evol. 4: 242-253.

Chaline, J ., and Graf, J.-D. (1988). Phylogeny of the Arvicolidae (Rodentia): Biochemical and paleontological evidence. J . Mammal. 69: 22-33.
Chevret, P., Denys, C., J aeger, J .-J ., Michaux, J ., and Catzeflis, F. M. (1993). Molecular evidence that the spiny mouse (Acomys) is more closely related to gerbils (Gerbillinae) than to true mice (Murinae). Proc. Natl. Acad. Sci. USA 90: 3433-3436.

Crowcroft, P. (1966). "Mice All Over," Foulis, London.

DeWalt, T. S., Sudman, P. D., Hafner, M. S., and Davis, S. K. (1993). Phylogenetic relationships of pocket gophers (Cratogeomys and Pappogeomys) based on mitochondrial DNA cytochrome b sequences. Mol. Phylogenet. Evol. 2: 193-204.

Dubois, J. F., Catzeflis, F. M., and Beintema, J. J. (1999). The phylogenetic position of "Acomyinae" (Rodentia, Mammalia) as sister group of a Murinae + Gerbillinae clade: Evidence from the nuclear ribonuclease gene. Mol. Phylogenet. Evol. 13: 181-192.

Ducroz, J .-F., Volobouev, V., and Granjon, L. (1998). A molecular perspective on the systematics and evolution of the genus Arvicanthis (Rodentia, Muridae): I nferences from complete cytochrome b gene sequences. Mol. Phylogenet. Evol. 10: 104-117.

Elwood, R. W. (1985). Inhibition of infanticide and onset of paternal care in male mice (Mus musculus). J . Comp. Psychol. 99: 457- 468.

Furano, A. V., Hayward, B. E., Chevret, P., Catzeflis, F., and Usdin, K. (1994). Amplification of the ancient murine Lx family of long interspersed repeated DNA occured during the murine radiation. J. Mol. Evol. 38: 18-27.

Gadaleta, G., Pepe, G., De Candia, G., Quagliariello, C., Sbisa, E., and Saccone, C. (1989). The complete nucleotide sequence of the Rattus norvegicus mitochondrial genome: Cryptic signals revealed by comparative analysis between vertebrates. J. Mol. Evol. 28: 497-516.

Gerlach, G. (1996). Emigration mechanisms in house mice-A laboratory investigation of the influence of social structure, population density, and aggression. Behav. Ecol. Sociobiol. 39: 159-170.

Gerlach, G. (1998). Impact of social ties on dispersal, reproduction and dominance in feral house mice (Mus musculus domesticus). Ethology 104: 487-499.

Gill, A., Petrov, B., Zivkovic, S., and Rimsa, D. (1987). Biochemical comparisons in Yugoslavian rodents of the families Arvicolidae and Muridae. Z. Säugetierk. 52: 247-256.

Graf, J .-D., and Scholl, A. (1975). Variations enzymatiques et relations phylétiques entre neuf espèces de Microtinae (Mammalia, Rodentia). Rev. Suisse Zool. 82: 681- 687.

Hasegawa, M., Kishino, H., and Yano, T. (1985). Dating of the human-ape splitting by a molecular clock of mitochondria. J . Mol. Evol. 22: 160-174.

Hillis, D. M., and Huelsenbeck, J. P. (1992). Signal, noise, and reliability in molecular phylogenetic analysis. J . Hered. 83: 189195.

Hurst, J. L. (1986). Mating in free-living wild house mice. (Mus domesticus). J . Zool. London 210: 623- 628.

Irwin, D. M., Kocher, T. D., and Wilson, A. C. (1991). Evolution of the cytochrome b gene of mammals. J . Mol. Evol. 32: 128-144.

J acobs, L. L. (1978). Fossil rodents (Rhizomyidae and Muridae) from Neogene Siwalik deposits, Pakistan. Mus. North. Arizona Press Bul. Ser. 52 I-IX: 1-103.

J acobs, L. L., Flynn, L. J ., and Downs, W. R. (1989). Neogene rodents of southern Asia. In "Papers on Fossil Rodents in Honor of Albert Elmer Wood" (C. C. Black and M. R. Dawson, Eds.), pp. 157-177. Nat. Hist. Mus. Sci. Ser. No. 33, Los Angeles County.

J acobs, L. L., Flynn, L. J ., Downs, W. R., and Barry, J . C. (1990). Quo vadis, Antemus? The Siwalik muroid record. In "European Neogene Mammal Chronology" (E. H. Lindsay, V., Fahlbusch, and P. Mein, Eds.), pp. 573-586. Plenum, New York.

J aeger, J .-J ., Tong, H., and Denys, C. (1986). Age de la divergence Mus-Rattus: Comparison des donnees paléontologiques et moléculaires. C. R. Acad. Sci. Paris 302: 917-922. 
Kishino, H., and Hasegawa, M. (1989). Evaluation of the maximum likelihood estimate of evolutionary tree topologies from DNA sequence data, and the branching order in huminoidea. J . Mol. Evol. 29: $170-179$.

König, B., and Markl, H. (1987). Maternal care in house mice. Behav. Ecol. Sociobiol. 20: 1-9.

Lara, M. C., Patton, J. L., and Da Silva, M. N. F. (1996). The simultaneous diversification of South American echimyid rodents (Hystricognathi) based on complete cytochrome b sequences. Mol. Phylogenet. Evol. 5: 403- 413.

Lessa, E. P., and Cook, J . A. (1998). The molecular phylogenetics of Tuco-Tucos (genus Ctenomys, Rodentia: Octodontidae) suggests an early burst of speciation. Mol. Phylogenet. Evol. 9: 88-99.

Ma, D. P., Zharkikh, A., Graur, D., VandeBerg, J . L., and Li, W. H. (1993). Structure and evolution of opossum, guinea pig, and porcupine cytochrome b genes. J . Mol. Evol. 36: 327-334.

McClintock, M. K. (1983). The behavioral endocrinology of rodents: A functional analysis. Bioscience 33: 573-577.

Meyer, A. (1994). Shortcomings of the cytochrome b gene as a molecular marker. Trends Ecol. Evol. 9: 278-280.

Misonne, X. (1969). African and Indo-Australian Muridae: Evolutionary trends. Ann. Mus. R. Afr. Centr. Tervuren Zool.: 1-172.

Musser, G. G., and Carleton, M. D. (1993). Family Muridae. In "Mammal Species of the World: A Taxonomic and Geographic Reference" (D. E. Wilson and D. Reeder, Eds.), pp. 501-755. Random House (Smithsonian Inst. Press), New York.

Niethammer, J ., and Krapp, F. (1978). "Handbuch der Säugetiere Europas," Akademische Verlagsgesellschaft, Wiesbaden.

Niethammer, J ., and Krapp, F. (1982). "Handbuch der Säugetiere Europas," Akademische Verlagsgesellschaft, Wiesbaden.

Nikoletopoulos, N. P., Chondropoulos, B. P., and Fraguedakis-Tsolis, S. E. (1992). Albumin evolution and phylogenetic relationships among Greek rodents of the families Arvicolidae and Muridae. J . Zool. London 228: 445- 453.

Prager, E. M., Tichy, H., and Sage, R. D. (1996). Mitochondrial DNA sequence variation in the eastern house mouse, Mus musculus: Comparison with other house mice and report of a 75-bp tandem repeat. Genetics 143: 427-446.
Reyes, A., Pesole, G., and Saccone, C. (1998). Complete mitochondrial DNA sequence of the fat dormouse, Glis glis: Further evidence of rodent paraphyly. Mol. Biol. Evol. 15: 499-505.

Robinson, M., Catzeflis, F., Briolay, J ., and Mouchiroud, D. (1997). Molecular phylogeny of rodents, with special emphasis on murids: Evidence from nuclear gene LCAT. Mol. Phylogenet. Evol. 8: 423434.

Robitaille, J . A., and Bovet, J . (1976). Field observations on the social behaviours of the Norway rat Rattus norvegicus (Barkenhout). Biol. Behav. 1: 289-308.

Sambrook, J ., Fritsch, E. F., and Maniatis, T. (1989). "Molecular Cloning: A Laboratory Manual," Cold Spring Harbor Laboratory Press, Cold Spring Harbor, NY.

Sarich, V. M. (1985). Rodent macromolecular systematics. In "Evolutionary Relationships among Rodents" (W. P. Luckett and J .-L. Hartenberger, Eds.), pp. 423-452. Plenum, New York.

Smith, M. F., and Patton, J . L. (1993). The diversification of South American murid rodents: Evidence from mitochondrial DNA se quence data for the akodontine tribe. Biol. J . Linn. Soc. 50: 149177.

Smith, M. F., and Patton, J . L. (1999). Phylogenetic relationships and the radiation of sigmodontine rodents in South America: Evidence from cytochrome b. J . Mammal. Evol. 6: 89-128.

Swofford, D. L. (1998). PAUP: Phylogenetic analysis using parsimony. Illinois Natural History Survey, Champaign.

Thomas, W. K., and Martin, S. L. (1993). A recent origin of marmots. Mol. Phylogenet. Evol. 2: 330-336.

Verheyen, E., Colyn, M., and Verheyen, W. (1995). The phylogeny of some African muroids (Rodentia) based upon partial mitochondrial cytochrome b sequences. Belg. J . Zool . 125: 403- 407.

Vogel, P., Maddalena, T., Mabille, A., and Paquet, G. (1991). Confirmation biochimique du statut spécifique du mulot alpestre Apode mus alpicola Heinrich, 1952 (Mammalia, Rodentia). Bull. Soc. Vaud. Sc. Nat. 80.4: 471- 481.

Wettstein, P. J ., Strausbauch, M., Lamb, T., States, J ., Chakraborty, R., J in, L., and Riblet, R. (1995). Phylogeny of six Sciurus aberti subspecies based on nucleotide sequences of cytochrome b. Mol. Phylogenet. Evol. 4: 150-162. 